\title{
A MULHER AUSENTE POR MEIO DA TERRA, DA ÁGUA E DA VOZ DE ADALGISA NERY
}

\section{A MULHER AUSENTE THROUGH THE EARTH, THE WATER AND THE VOICE OF ADALGISA NERY}

\author{
Éverton Barbosa CORREIA ${ }^{1}$
}

\begin{abstract}
Resumo: Intenta-se aqui pontuar melhor o lugar de Adalgisa Nery na historiografia literária brasileira, cuja obra será abordada sob a perspectiva de uma possível expressão individual recortada em três poemas - assinalados pelos elementos terra, água e voz - coligidos no livro A mulher ausente (1940), o qual será abordado em sua edição princeps. Estas três composições serão cotejadas com a poesia de seu marido já falecido e publicada postumamente na Antologia de poetas brasileiros bissextos contemporâneos (1946). Entendida como uma voz peculiarmente individualizada, a poesia de Adalgisa Nery terá como ponto de apoio a recepção por Mário de Andrade, o primeiro e único crítico de sua obra em $O$ empalhador de passsarinho (1946), que também será considerado como instrumental de leitura para atualizar sua compreensão autoral.
\end{abstract}

Palavras-chave: Historiografia literária. Poesia Brasileira moderna. Vida literária. Estilo. Adalgisa Nery.

\begin{abstract}
This paper aims to better point Adalgisa Nery's place in the Brazilian literary historiography. Her work will be addressed under the perspective of a possible individual expression cut in three poems - marked by the earth, water and voice elements - collected in the book A mulher ausente (1940), which will be approached in its princeps edition. These three compositions will be compared to the poetry of her late husband and published posthumously in Antologia de poetas brasileiros bissextos contemporâneos (1946). Understood as a peculiarly individualized voice, Adalgisa Nery's poetry will be supported by Mário de Andrade's reception, the first and only critic of her work in $O$ empalhador de passsarinho (1946), which will also be considered as reading instrument to update her authorial understanding.
\end{abstract}

Keywords: Literary historiography. Modern Brazilian poetry. Literary life. Style. Adalgisa Nery.

Compulsando a biblioteca de Murilo Mendes em momento anterior à sua reunião pelo Museu de Arte Murilo Mendes (MAMM) da Universidade Federal de Juiz de Fora (UFJF), que não existia à época de sua pesquisa, Júlio Castañon Guimarães coligiu uma dúzia de dedicatórias subscritas nos livros do poeta para ilustrar o cordão de seus interlocutores, que em ordem inversa tem a seguinte disposição: Breton, Léger, Michaux, Char, Magritte, Luciana, Tzara, Aleixandre, Nemésio, Segall, Oswald e Adalgisa. Deve ter havido alguma razão pontual para o crítico colocar o nome de Adalgisa Nery como primeiro da lista, já que não havia ordenamento cronológico ou alfabético para a enumeração. A estratégia de reunir os

\footnotetext{
${ }^{1}$ Doutor em Letras pela Universidade de São Paulo (USP). Professor Adjunto do Instituto de Letras da Universidade do Estado do Rio de Janeiro (UERJ). E-mail: evertonbcorreia@gmail.com
} 
interlocutores com os quais o autor trocara livros e dedicatórias interessa porque incide diretamente sobre os discursos historiográficos, devido à especificidade do registro, que ali recebe a seguinte valoração: "Não que se confundam essencialmente com poemas, mas contém condensadamente - como aliás é próprio da poesia - algumas doses de informação, rápidos toques de biografia" (GUIMARÃES, 1986, p. 11).

A mulher ausente veio a lume em fevereiro de 1940 e sendo o segundo livro de Adalgisa Nery confirma sua apresentação ao público como poetisa, uma vez que seu livro anterior, Poemas (1937), havia sido publicado há apenas três anos. Com um lapso de tempo tão curto, é previsível que houvesse o desdobramento de um no outro e a previsão se cumpriu: Murilo Mendes, que organizara o anterior, comparecerá nesta publicação também como dedicatória de poema, tal como antes. A diferença é que agora ele vai ter a companhia de Jorge de Lima e Augusto Frederico Schmidt, para ficar em três oficiais do ofício, com forte influência do catolicismo. A informação interessa porquanto permite um diagnóstico da produção da época, para a qual o catolicismo se fazia um imperativo categórico para a poesia e para a crítica do momento, a considerar a figura solar de Tristão de Athayde, que veio a substituir o exercício da crítica pela militância católica. A tal liturgia católica reverberava na poesia de todos os poetas da época, notadamente na daqueles que agora seriam homenageados pela viúva, após ela ter vivido simplesmente como a esposa de Ismael Nery. O conglomerado de informações ganha relevo, se levarmos em conta a força do título que anuncia a ausência de certa mulher.

Uma vez que a autora acumula naturalmente a condição de ser mulher, sugere-se uma possível contradição entre a ausente anunciada e a mulher que se faz presente na autoria do livro. Descartada a hipótese de a ausente ser outra que não ela, a própria autora se faz a um só tempo presente e ausente: presente enquanto subjetividade discursiva e ausente como objeto do discurso que profere. Por isso, vale a pena insistir um pouco mais sobre o que a torna ausente na matéria literária, para chegarmos ao modo como a autora se faz presente nos poemas que produz. Tal ausência pode referir sua dificuldade de acesso ao universo masculino, para o qual sua voz soaria um eco remoto do falecido marido e, por conseguinte, como uma alteridade estendida de um sujeito que a identifica pelo que ele fizera e está associado ao sobrenome comum, e não pelo que ela efetivamente produziu ou fosse. Nesse passo, é como se ela só pudesse ser algo por meio daquilo que se lhe revela de sua alteridade, investida de um superego que se sobrepõe e sobrepuja sua identidade autoral. Se for assim, tudo o que Adalgisa Nery quisesse ser só estaria disponível através de algo que seu falecido marido chancelasse como uma credencial sua, a despeito de seu falecimento, fosse como homem ou como poeta. 
Conforme fosse, estaria justificada a predileção mútua e recíproca por Murilo Mendes, bem como a performance verbal decalcada do desempenho verbal do marido, que não era um poeta qualquer, ao menos como foi coligido na Antologia dos poetas brasileiros bissextos contemporâneos por Manuel Bandeira.

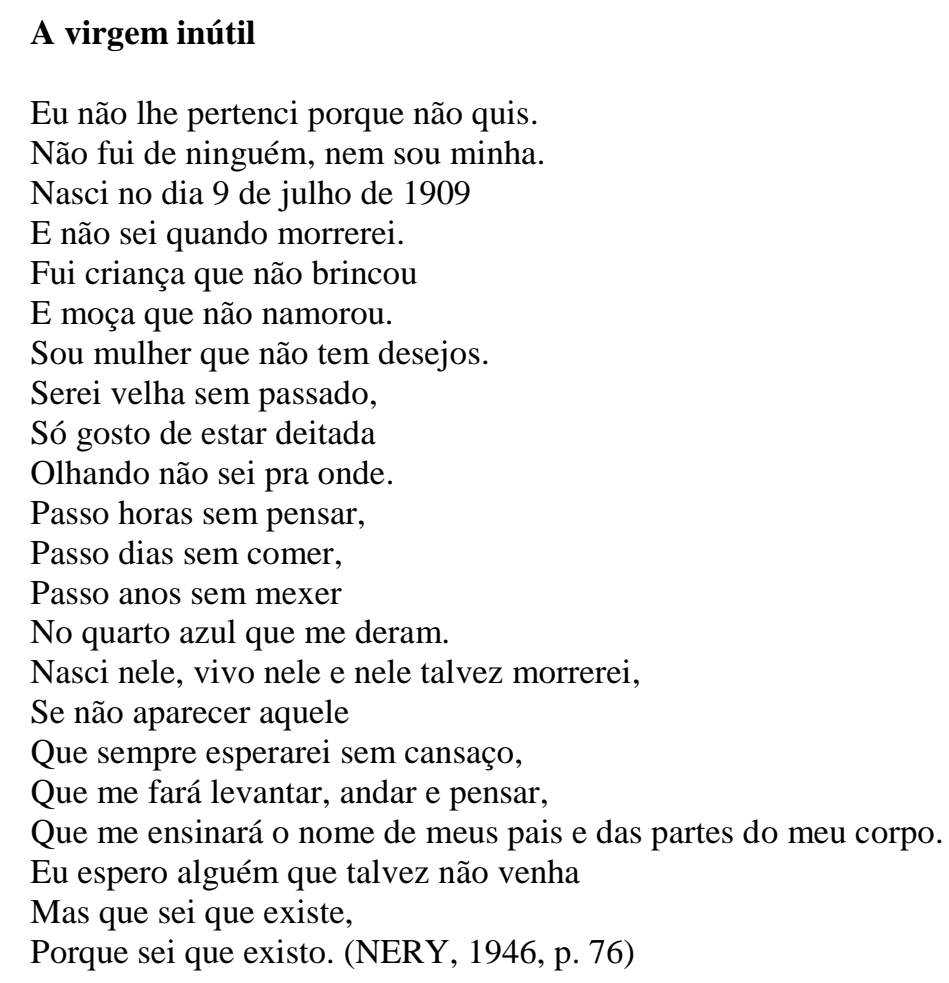

Dos versos acima, há uma informação fictícia: a de que ela tivesse nascido em 9 de julho de 1909, quando, na verdade, Adalgisa veio ao mundo aos 29 de outubro de 1905 e Ismael, aos 9 de outubro de 1900. A diferença de 5 anos de idade entre os dois poderia ter se dissipado ao longo do tempo, mas não por ocasião do casamento, quando ela tinha 15 anos e ele 20. Tratavase, portanto, de uma relação em que havia uma clara ascendência do adulto sobre a jovem, ainda adolescente. Daí a veracidade das informações poderem ser conferidas em outros versos: "Fui criança que não brincou/ E moça que não namorou", o que se aplica bem à autora.

Diante da transcrição do poema como um todo, surge uma compreensão de arte em que fica evidente a projeção de Ismael Nery na figura de sua mulher para impostar sua voz enquanto poeta - e certamente sua expressão individual de pintor -, ao passo que abre o precedente técnico ou artístico para que a voz impostada de Adalgisa repercuta na figura de certo Ismael, cuja imagem reduplicada no sujeito que a poetisa manipula faz com que o seu amado apareça como a encarnação da finitude mais concreta, que perdura na sua escrita tal como se percebe nos versos adiante. Aliás, é bem sabido que a "transferência" se constitui como um expediente 
psíquico, que é compulsivamente acionado em momentos de perda. Se a perda do marido engatilhou a projeção pública de Adalgisa Nery para saldar aquela ausência, somente quando convertida em objeto de escrita a perda passa a ter um valor positivo, porquanto inscreve um artefato estético, que suplanta a lamentação e se converte em algo produtivo, como se vê.

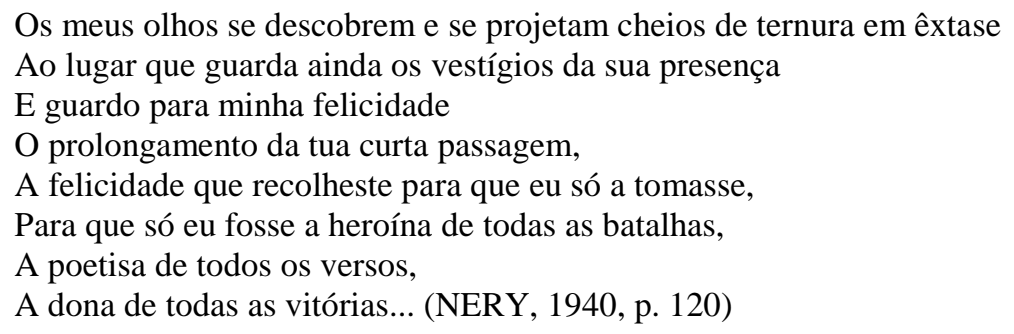

Os versos acima foram retirados do "Canto para o ausente", único poema que remete ao título do livro, ao contrário do que acontece com volumes que reproduzem metonimicamente o título de algum dos seus poemas. Tal assimetria entre a nomeação do livro e a dos poemas vem a ser um equivalente formal da conduta dissonante que se espraia entre as composições ali reunidas. Por isso, a parte que é cada um dos seus poemas não ilustra o todo que é o livro como uma correspondência imediata ou estrita, porque amparado por uma fatalidade constitutiva daquela expressão em movimento, que repele de antemão qualquer identidade composicional ou construtiva, porque jamais será simples reprodução de qualquer credencial redutível ao âmbito individual, seja de espaço, de tempo, de religião ou de sexo.

Por meio de um princípio de composição autônomo, os poemas enunciam entre si uma experiência de vida irredutível à convencionalização formal, para a qual cada composição inscreve e enumera uma parte daquela experiência na linha evolutiva da expressão autoral, cujo acúmulo literário indica mais um traço da existência do que um experimento verbal, porque refuga todo entendimento da forma poética praticada àquelas alturas. Na sua pena, o artefato linguístico parece só ter cabimento à proporção que refere uma experiência que é histórica, subjetiva e religiosa, porquanto desestabiliza o contingenciamento da expressão mundana como correlato da transcendência. Por conta disso, torna-se patente certa sensação de incompletude que salta do seu fraseado, o qual inscreve um estilo cambiante, onde ainda tremula o saldo perdulário do vivido. Daí tornar-se apreciável até mesmo a depuração de certo inacabamento dos versos, que parecem querer saltar da página em que vibram para a vida cotidiana, de onde nunca encontram termo justo, justamente porque se pautam pela imprecisão. Nunca é um correlato verbal exato o que se descola da expressão de Adalgisa Nery, que parece estar além de julgamentos alheios, ao menos tal como se cristalizou para a história literária. 
Assim como a imagem da mulher ausente é reduplicada da ausência do marido falecido, por outra via a autora se faz ausente entre os amigos e confrades partilhados conjuntamente com ele, os quais lhe conferem o epíteto de escritora, diante do qual paira esfumada uma sombra projetada do perfil de outrem, seja da mulher que quisera ser, do marido que teve ou de seus amigos em comum, agora tornados exclusivos dela. De um modo ou de outro, a tônica do livro é dada por um catolicismo compulsivo que se espalha ao longo da publicação. Entendamos que esta liturgia não se contrapõe a ingerências governamentais ou fosse infenso a agremiações comunistas, cuja inscrição no livro pode ser identificada pelas dedicatórias de poemas às figuras de Gustavo Capanema - representante do governo - e de Cândido Portinari - comunista confesso. Com esse repertório de informações, aureola-se o universo de Ismael Nery, cujos despojos foram mais sociais do que financeiros, uma vez que o seu devido reconhecimento só viesse a se dar muito posteriormente, sem que Adalgisa Nery pudesse usufruir do patrimônio legado pelo marido de imediato, porque ficou restrito durante muito tempo à sua dimensão simbólica, desvinculada do correspondente financeiro de que ela precisava, inclusive para sustentar dois filhos, tendo já falecido cinco outros.

Delineada a ambiência em que a poeta estava envolta quando da publicação, ancorada nas dedicatórias supracitadas, o volume publicado ainda demanda outras observações: tendo sido editado pela José Olympio editora, "Deste livro foram tirados, fora de comércio, vinte exemplares em papel vergê, numerados e assinados pela autora. Os desenhos são de Cândido Portinari. A capa é de Santa Rosa", conforme consta na edição autografada antes da composição de abertura do livro, "Poema à filha triste". Tal advertência editorial reproduz quase na íntegra a do livro de estreia, onde constava a reprodução do seu retrato por Portinari. A diferença agora ficou por conta dos desenhos exclusivos para a nova publicação que o pintor paulista fez, como desdobramentos do retrato da escritora, ampliando o raio da interlocução. Se tudo isso dá a dimensão de que aquela publicação já nascera clássica, não foi exatamente este o destino do volume para o público consumidor de poesia nas décadas seguintes, para o qual Adalgisa Nery simula um perfil desfigurado, sem sequer considerar os retratos que the foram esculpidos por Portinari ou pelo próprio marido.

O livro A mulher ausente mesmo se constitui por uma coleção de 63 poemas, tal como consta na edição original de 1940. Desta coleção, aqui nos ocuparemos de apenas três, menos pela amostragem do que pela crença de que o quanto se perde em perspectiva ganha-se em análise, a pretexto de dimensionar melhor o desempenho verbal da poeta, para averiguar a verticalidade de sua intervenção, mais do que a quantidade de leitores que conseguiu 
arregimentar ou de livros que conseguiu vender - o que não seria pouco -, a considerar quem se apresentou primeiramente como fazedora de versos. Para tanto, as composições líricas escolhidas foram as seguintes: "Quando eu um dia me transformar em água" e "Voz nos meus múltiplos". Daí se depreende a existência de elementos que nucleiam, respectivamente, cada poema como referências constitutivas à expressão autoral, a saber: a terra, a água e a voz. Uma vez identificadas as referências que se desdobram nos significantes utilizados pela escritora, elas só interessam à proporção que apontam para sua caracterização estilística, objetivo primeiro da análise dos poemas. Todas essas variáveis só importam na medida em que possam indicar a persona textual construída por Adalgisa Nery, conforme se anuncia.

\title{
A amada é como a terra
}

\author{
Agachado, com a boca bem colada ao solo \\ Fala para que a tua voz penetre na terra \\ E abasteça de harmonia e de vigor o grão que vai nascer. \\ Mergulha a tua voz no solo para que os ramos dos arbustos \\ Tocados pelos ventos das manhãs \\ Sejam um misto de amargor e de alegria \\ Acompanhando os desolados com essa melodia. \\ Fala bem dentro da terra e dize palavras de consolo \\ Que assim as flores terão quando brotarem \\ A beleza eterna em seus perfumes e em suas cores. \\ Cola a tua boca ao solo \\ E envia com os sons da tua garganta \\ Os teus insuperáveis pensamentos de Unidade \\ Para que eles caminhem subterraneamente \\ E rebentem no meio de outros povos \\ Cantando a glória da Verdade e da Fraternidade. \\ Abre com tuas mãos uma fenda na terra \\ Encosta tua boca aflita e diz bem no fundo a raiz dos teus tormentos \\ Para que a água e o fogo central dissolvam teus lamentos. \\ Cola a boca no ventre da Amada \\ E fala a seu corpo \\ Para que os seus filhos transportem a tua harmonia pelos tempos infindáveis \\ E possas ouvi-la em cada homem, em cada flor, \\ $\mathrm{Na}$ intensidade de todos os perfumes \\ E nos milésimos reflexos de cada cor!... (NERY, 1940, p. 17-18)
}

Quatro palavras acima estão grafadas excepcionalmente com iniciais maiúsculas: "Unidade", "Verdade", "Fraternidade" e "Amada". As três primeiras ecoam entre si porque têm a mesma terminação, produzindo um efeito semântico particular, que parece se desprender de uma conotação religiosa para outra, possivelmente política, à qual a Amada se contrapõe, porque não dá curso livre à articulação das palavras, antes a interrompe. Tudo isso adquire ressonância privilegiada na caixa acústica que é o poema se considerarmos o descompasso entre o título e o texto. O título "A amada é como a terra" sugere uma exposição da afirmativa, enquanto que todo o poema é constituído por ações condicionadas pelo uso do imperativo, que Revista Graphos, vol. 21, n 2, 2019| UFPB/PPGL | ISSN 1516-1536 
reclama uma voz, colada ao solo, que fale, que envie sons cantando, que encoste a boca e diga, que cole a boca e fale. $\mathrm{O}$ efeito daí decorrente indica a todo tempo uma vontade de fala, um desejo de expressão, sobretudo porque a referência discursiva é um "tu”, com o qual o verbo concorda quase escrupulosamente do início ao fim do poema, dando a entender que o interlocutor é próximo ao sujeito que fala e conferindo um tom castiço ao discurso, de cariz bíblico.

Curioso mesmo é que tal interlocutor seja instado impositivamente a tergiversar, a berrar ou a cantar em direção à terra até certa altura do poema, a partir de quando o "tu" deve se voltar para a Amada. De acordo com tal observação, podemos tomar o poema como estando estruturado em duas partes desiguais: uma maior (até o verso 19), em que o "tu" é impelido a interagir verbalmente com a terra; e outra menor (entre os versos 20 e 25), em que o mesmo "tu" deve se pronunciar à Amada, que substitui a terra. A partir daí, é de se presumir algum grau de equivalência entre a terra e a Amada, uma vez que ambas ocupam o mesmo lugar discursivo no corpo do poema, reforçado pela indicação do título: "A amada é como a terra". Convém especular ainda uma vez sobre o título, já que sendo como a terra, não é a terra exatamente e tal observação diz muito da composição como um todo.

Ora, se a cada parte do poema corresponde um tratamento do "tu", que se altera inclusive devido à mudança do objeto, ocasionalmente a Amada e preponderantemente a terra, essa bifurcação de interesses no enunciado do poema acaba por expandi-lo, não só porque a terra se transfere e se transfigura na Amada, mas também porque tal expansão se dá do âmbito geral despersonalizado para o particular identificado pela Amada. No poema tudo colabora para a expansão da terra que é contradita pela expansão da Amada, à qual se contrapõe como se não houvesse possibilidade de equivalência entre as expansões de uma e de outra. A Amada não cresce nem se expande por si, mas se reproduz na prole como sendo a maneira mais corriqueira de ilustrar a natureza, o que parece ser mais do que suficiente para quem se quer projetada "na intensidade de todos os perfumes/ E nos milésimos reflexos de cada cor!...”. Se a promessa parece sedutora, o seu cumprimento não é tanto assim, devido à intervenção da Amada, uma vez que a expressão adalgisaneriana não se restringe à manipulação de significantes, mas se expande na exploração de ideias até o seu limite inteligível. Nada disso teria recurso sem a mediação produtiva do vernáculo tal como está disposto singularmente no idioleto acionado pela poetisa. 


\title{
Quando eu um dia me transformar em água
}

\author{
Quando eu um dia me transformar em flor, \\ Enfeitar os altares, acompanhar as noivas \\ E puder ficar escondida assistindo suas noites nupciais, \\ Quando eu for colocada na mão parada e fria do cadáver, \\ Quando o cheiro de minhas pétalas se misturar com as carnes decompostas \\ E o limo dos corpos enlamear minha haste e meu pólen \\ Eu serei mais tua \\ Te darei mais que a terra. \\ Irei às entranhas do solo, \\ Desprezarei as raízes das figueiras, das mangueiras e trepadeiras, \\ Me afundarei à procura do veio d'água que a mata não mostrou aos animais, \\ Irei me reunir aos canais subterrâneos que me levarão aos lagos em que te banharás \\ E então serei mais tua \\ Me esfregarás em ti, aliviarei teu corpo do ardor do sol, \\ Me beberás e sentirás que só eu te mitigo a sede \\ E quando sentires a língua pastosa se enrolando em tua boca no último suspiro \\ Eu serei a única a penetrar e aliviar teu corpo derrotado, \\ Só eu transformada em gotas percorrerei tuas carnes consumidas \\ E serei mais tua. \\ Mais contigo do que sendo flor, \\ Muito mais do que sendo MULHER! (NERY, 1940, p. 54-55)
}

Conforme consta na edição príncipe, deste poema arrastado se sobressai a duração dos versos esticados ao longo das linhas, ocupando toda extensão da página que parece não conter o fluxo verbal que irrompe sensações confusas, às vezes repetidas com mínimas variações que alteram substancialmente o seu sentido, tais como a do título para o primeiro verso, consoante a qual a palavra "flor" substitui a "água". Tal variação, que impede a repetição do verso e cria uma homologia entre água e flor, interfere no sentido simbólico do poema quando as palavras são remetidas à mulher, que explicitamente fecha o poema com letras garrafais seguidas por uma exclamação. Esta condição exclamativa da mulher em caixa alta que fecha o poema dá o que pensar quando confrontada aos significantes "água" e "flor", a que lhe remetem. Água e flor seriam desdobramentos da terra que a identificava no poema anterior e à qual agora se contrapõe, porque não é mais no terreno da fertilidade em que estamos pisando, e sim no da decomposição. Decomposição física e concreta, à qual a mulher se opõe em maiúsculas, em água e em flor.

Por outra, só porque aquela subjetividade se quer "flor" é que permite sua fusão com a terra, com a qual haverá de se unir como concorrente última, pois pode mais do que a própria terra que calcina e dilacera o cadáver invadido por outros corpos estranhos, que passam a constituí-la. Constituição similar à da própria terra, com a qual a mulher investida de flor rivaliza, de acordo com o enunciado estendido dos versos 4 ao 8. Este trecho exerce função nuclear no poema à proporção que sintetiza o procedimento de confrontar versos caudalosos a 
versos secos. Os caudalosos têm a propriedade de descrever a intenção ou o movimento do que aquela subjetividade deseja fazer e os secos dizem o que ela quer ser ou será. A oposição ganha relevo quanto mais considerarmos a disposição sintática de uma subordinada temporal travestida de condicional, completada pelo sentido da oração principal no futuro, cuja inversão lhe dá o arremate no final da frase. A hipotética simplicidade da frase será contradita pela inversão da oração principal, cujo sentido só se revela por último, ficando em suspenso, como um som sustenido que repercute no acorde posterior, quando sua função se efetiva. Afinal, ela só será dele e lhe dará mais que a terra, após cumprir tais e quais tarefas. Ou seja, ela não é dele espontaneamente, o que a disposição das orações enuncia e pode ser entendido como uma solução formal para o dilema vivido por aquela subjetividade.

Os versos seguintes reproduzem aquele mesmo procedimento de intercalar orações longas e orações curtas, cujo sentido só se completa diante de declarações já sabidas: "E serei mais tua", com a variação de "E então serei mais tua", onde reside o núcleo do enunciado do poema com o único verso que se repete como um refrão variável. Ora, levando em conta que o enunciado do refrão se constitui por meio do intensificador "mais", podemos entender que aquela subjetividade já era do "tu" a quem se reporta, mas não de modo suficiente. Tal insuficiência é que move o poema como se houvesse possibilidade de ela se redimir perante ele, não sendo apenas o que já era, mas muito "mais" do que podia ser. O intensificador constante no verso que se repete "E então serei mais tua", que pode ser lido como um refrão, aparece ainda em três outros versos: "Te darei mais que a terra", "Mais contigo do que sendo flor" e “Muito mais do que sendo MULHER!". Todos estes versos são antecedidos por aquele verso travestido de estribilho "E então serei mais tua", o que dá a entender que somente quando for "mais" dele tais outras propriedades se lhe revelarão, seja em relação à terra, à flor ou à mulher, porque quando for a água em que busca se transformar, será por contiguidade simbólica muito mais dele e muito mais do que pode ser. Uma vez que estamos diante da finitude mais concreta à qual aquela subjetividade não quer se resignar, assim, beira o limite do não ser que ela, circunstancialmente, figura ou quer representar, ao menos na poesia.

A título de ilustração, conviria enumerar os versos em que constam figurações do corpo humano presentes neste poema do livro A mulher ausente: 1. "Quando eu for colocada na mão parada e fria do cadáver"; 2. "Quando o cheiro de minhas pétalas se misturar com as carnes decompostas"; 3. "E o limo dos corpos enlamear minha haste e meu pólen"; 4. "Me esfregarás em ti, aliviarei teu corpo do ardor do sol"; 5. "E quando sentires a língua pastosa se enrolando em tua boca no último suspiro"; 6. "Eu serei a única a penetrar e aliviar teu corpo derrotado"; 
7. "Só eu transformada em gotas percorrerei tuas carnes consumidas". Diante da sequência, o que se evidencia é o "tu" a quem aquele "eu" se refere e está, indiscutivelmente, com as carnes consumidas e decompostas. Isso não se faz causa suficiente para demover aquela subjetividade de continuar insistindo num contato, mais do que físico, carnal com o cadáver que a deveria ostentar como a uma flor. A flor que, materialmente, colabora para a decomposição do cadáver, neste caso, é tomada como figura de expansão e dilatação do sujeito que absorve as propriedades do objeto que o cadáver ilustra. $\mathrm{O}$ corpo dilatado pela putrefação vem a ser símile da sensibilidade expandida em flor, em água ou em mulher, que se expandem a um só tempo, sendo "mais" do que podem ser como contrapartes de um corpo que não é nada além de uma figuração para que a sensibilidade de Adalgisa se projete autonomamente, extrapolando a materialidade física do corpo que, por reduplicação, expande-a, amplia-a e a dilacera, tal qual ele que está putrefato. Eis o canal de projeção da sua voz, sintonizada diversamente neste outro poema.

\section{Voz nos meus múltiplos}

Há uma voz que não percebo,

Em que parte da minha alma se esconde

E que paulatinamente nega

O que vejo, o que sinto

E até o que me vem de longe.

Não crê que minha existência seja um número

Que depende da Unidade

E constantemente repugna e se enoja da minha humanidade.

Com o frio dos túmulos

Ela impede o movimento da minha mão

E esmaga a minha boca

Num volume de montanha de silêncio e solidão.

Como um bólido afastando nuvens,

Rasgando chuvas, fendendo o solo

Ela corta meu coração

Polo a polo.

Está feliz sempre que me vê atormentada

E canta canções suaves

Quando minha esperança é espancada.

Igual à derradeira ave do Dilúvio

Procuro onde pousar

$\mathrm{Na}$ ânsia de fugir

E de mim descansar.

Voz que me acompanha nos seus múltiplos,

Que me distancia das matérias vivas,

Que me separa eternamente da Unidade onde fui gerada,

Que me pulveriza no tempo

E me enxota da visão Amada!... (NERY, 1940, p. 70-71)

Tal como o poema anterior, este também é constituído por um jogo entre o título e um de seus versos, cujo enunciado reproduz o do título com uma variação mínima, que altera 
significativamente o sentido anunciado anteriormente, conforme está ilustrado na linha 24: "Voz que me acompanha nos seus múltiplos". Pois a conotação da voz tomada dos múltiplos de uma subjetividade, tal como consta no título, é muito diversa de quando é decalcada dos próprios múltiplos, que ela, a voz, dispõe. Havendo uma correlação possível entre os múltiplos daquela subjetividade e os múltiplos da voz, é necessário frisar que não são os mesmos, a considerar que o jogo em pauta passa por um espelhamento entre o sujeito e a voz que o reproduz em imagem côncava ou invertida. Trata-se, todavia, de uma voz que tem alma e vontade próprias e diversas do sujeito que a pronuncia, causando um descompasso entre a elocução e o sentimento subjetivo, conforme os versos informam: "Está feliz sempre que me vê atormentada/ E canta canções suaves/ Quando minha esperança é espancada.”

Progrediremos na reflexão sobre os múltiplos, se considerarmos a quantidade de possessivos que o poema carrega, com cinco incidências do pronome "minha", referindo-se à subjetividade em movimento e apenas uma ocorrência do pronome "seus", referindo-se à voz, coincidentemente, quando estabelece um vínculo entre a voz e os múltiplos, em franca oposição ao que está enunciado no título. Desdobrando a especulação pronominal, o oblíquo "me" tem seis ocorrências, sendo uma no quinto verso e as outras nos cinco últimos versos. Daí ao menos a duas constatações são decorrentes: 1. A subjetividade é feminina, devido à reincidência do possessivo "minha"; 2. A recorrência do oblíquo confere a suas ações certa passividade, uma vez que está sempre à mercê do que a voz fizer, ainda que a contragosto, mesmo que fique contrafeita.

Afora a repetição pronominal, há um substantivo abstrato que se repete nos versos 7 e 26 , que é "Unidade", sempre com inicial maiúscula. Esta "Unidade" maiúscula adquire tonalidade abstrata, que remete à transcendência, conforme o último enunciado que a acompanha: "Que me separa eternamente da Unidade de onde fui gerada". Se, de acordo com o verso, aquela subjetividade está apartada da tal Unidade de onde foi gerada, há um movimento mais insidioso entre a voz e a subjetividade, conforme a inscrição nos versos 6, 7 e 8: "Não crê que minha existência seja um número/ Que depende da Unidade/ E constantemente repugna e se enoja da minha humanidade.” A rima entre a Unidade maiúscula e a humanidade minúscula não parece solucionar o caso, que demanda alguma reflexão. Pois dispomos de uma voz que não crê, constantemente repugna e se enoja da humanidade na qual a Unidade ecoa.

Se insistirmos numa possível compreensão da Unidade, esbarraremos em duas hipóteses caudatárias da significação do vocábulo "número" ali grafado: a de que a existência da subjetividade é um número matemático que depende da Unidade; ou ainda, a de que sua 
existência é número circense que também depende da Unidade. Seja matematicamente ou como circo, o número explicita uma subjetividade que está cindida de sua Unidade, pela falta de crença, pela repugnância ou nojo da voz que se esconde nalguma parte de sua alma e ela mesma, ali expressa, não percebe. Com isso, a subjetividade se vê condicionada pela voz a que está sujeita, possivelmente sua própria voz, desdobrada de si. A falta de identidade já assinalada entre o título e o verso 24 vem a ser, por seu turno, símile e metonímia da falta de identificação entre a voz que fala e a persona que está sujeitada à voz, comprometendo sua própria condição subjetiva, já que aquela subjetividade em curso não tem controle algum sobre a relação de subordinação constituída no poema. Aquela persona apesar de impostar sua voz, está submetida passivamente ao que é dito, sem poder contradizer o enunciado que nega suas sensações, ao menos quando se refere ao que vê e ao que sente (verso 4).

Para finalizar a análise com a parte final do poema, fiquemos com o último dístico, que é desdobramento da frase que explicita a cisão da Unidade pela voz que nos seus múltiplos acompanha aquela persona sujeitada à própria voz, conforme se segue: "Que me pulveriza no tempo/ E me enxota da visão Amada!...". Todos os grifos para o significante "Amada" grafado com inicial maiúscula, tal como a Unidade já explorada e o Dilúvio, que constitui a locução adjetiva da ave com que a persona sujeitada se compara em busca de descanso, de fuga ou, ao menos, de pouso. Impressiona a conotação religiosa que se desprende das palavras Unidade, Dilúvio e Amada, grafadas com iniciais maiúsculas. Mas se a Unidade exerce função particular na compreensão do objeto que é o poema e o Dilúvio se constitui como locução que qualifica a ave com que a persona se identifica, a palavra Amada, mesmo com inicial maiúscula, é um adjetivo da visão que aquela subjetividade experimenta e da qual é enxotada.

Se em poema anterior a Amada era o objeto ao qual um inominado "tu" se reportava, agora a Amada é desprovida de sua condição objetal para se restringir a simples qualificativo de uma visão subjetiva. Grafada com inicial maiúscula e sucedida pela exclamação, tal qual a mulher de outro poema anterior, a Amada porosamente absorve as propriedades da visão que qualifica, de modo que a visão Amada passa a ser também dela, da Amada. Tal recurso materializa no próprio vocabulário do poema o que estava enunciado cursivamente antes, quer dizer, que a cisão da Unidade da sujeita Amada cria outra instância para sua expressão, que é contradita pela voz que a multiplica. De igual modo, a Amada cindida de sua condição de objeto amoroso incorpora um poder de qualificação que se estende de si mesma para o sujeito a quem deveria servir de objeto. Com isso, constitui-se a um só tempo como objeto e sujeito, na medida em que se grava na visão de quem a via, ao menos como um qualificativo que a identifica. 
Assim como o sobrenome Nery particulariza e qualifica Adalgisa, o adjetivo Amada se projeta na visão daquele que a amou e se confunde com a sua própria visão. Adalgisa passa a ser, por conseguinte, a visão Amada e portadora da visão da Amada, conforme se queira ler no poema ou na sua vida, justamente porque se conformou aos limites da voz por meio da qual se multiplica e não fica restrita a si mesma.

Não sendo exatamente esta a percepção de Mário de Andrade, em artigo depois coligido no volume $O$ empalhador de passarinho, ele identifica uma peculiaridade na voz impostada por Adalgisa Nery em relação aos seus interlocutores coevos. Como primeiro pronunciamento sobre a poetisa ainda desconhecida, o parâmetro de sua apreciação verbal é depurado de seus Poemas anteriores, mesmo sem o crítico saber que aquele seria o único pronunciamento a atravessar todo o século sobre aquela que estava efetivamente ausente no contexto da história literária brasileira e de algum modo ainda está. A pretexto de lhe consignar um lugar compatível com a sua intervenção lírica, assim se abre o artigo no qual lhe foi devotada uma interpretação singular, que se não servir pelo que afirma, decerto servirá pelo que revela em negativo ou em perspectiva, conforme se queira.

Em 1937 Adalgisa Nery tomava lugar de importância entre o nossos poetas, com o forte livro Poemas. Com as novas poesias que acaba de publicar não só ela conserva a posição conquistada, como a solidifica. É visível que a poetisa não se satisfez com a contribuição pessoal dos Poemas e produziu um belo esforço para acrescentar ao seu conceito já muito exato de poesia, um valor outro, mais íntimo e incorruptível, que a enriquecesse em nossa lírica. Embora a mudança não seja do branco para o preto, existe uma originalidade nova, talvez ainda não muito segura de si, nos poemas de agora. [...] Mas nos Poemas a originalidade era mais uma contingência, transpondo em feminilidade violenta, aquela solução poética de caráter mais ou menos bíblico, mais ou menos surrealisticamente apocalíptico, baseada nos valores líricos sucessivos das imagens surgidas, e tão desenvoltamente desligada da inteligência lógica, solução admirável firmada por Murilo Mendes e Jorge de Lima. Esta solução parece não satisfazer mais à personalidade, que se acentua, de Adalgisa Nery (ANDRADE, 1972, p. 227).

A referência que não quer calar é que, em 1935, havia sido publicado os dois livros de poemas Tempo e eternidade resultante da parceria de Murilo Mendes com Jorge de Lima sob as seguintes dedicatórias: “À memória de Ismael Nery” (MENDES, 1995, p. 244) e “A Ismael Nery na eternidade" (LIMA, 1992, p. 320), com as respectivas variações nos dois volumes. Como ambos os poetas já eram éditos e notórios, constituíam-se como referências obrigatórias à insurgente poetisa, menos pela sua adesão do que pelo seu diferencial aos procedimentos discursivos correntes. De acordo com o prisma observado, vale a insistência na insatisfação autoral com as imagens habilmente desligadas da lógica como anteparo formal para a mística decorrente da liturgia católica, que agora demanda uma subordinação à racionalidade 
expressional, que se encarna no verbo de Adalgisa. $O$ investimento lírico de agora na cursividade sintática viria sinalizar, pois, o moderado afastamento da experiência mesma de que a autora se reveste para traduzir-se em experiência estética e experiência linguística, sendo esta necessariamente subordinada à lógica e aquela a um determinado público, para interferir de maneira diversamente proporcional na convenção gramatical e na sensibilidade artística. A racionalidade imperativa como experiência transcendente atinge a um só tempo a dimensão religiosa, estética e linguística, amparadas por aquela subjetividade tão dissidente que clama e reclama para si o direito a uma voz. Cindida de si mesma, do seu tempo e da eternidade travestidos de elementos simbólicos gravados na atemporalidade, Adalgisa Nery se inscreve materialmente no seu verso, na sua voz reduplicada de outros. Operação semelhante foi identificada por Mário de Andrade no uso que a poetisa faz da rima, como se vê.

\begin{abstract}
O processo de rimar, já surgido esporadicamente nos Poemas, agora se sistematiza. Era, de resto, natural que a importância da rima se impusesse à artista de $A$ mulher ausente, porque a sua atitude poética elevou-a a... socializar a sua poesia nova. Ora, a rima é elemento socializador. É um dos elementos musicais de que serve-se a poesia para coletivizar o indivíduo. Ela obriga a uma compreensão mais geral, mais unânime da palavra que rimou, passando esta a funcionar menos em seu sentido intelectual e mais em sua dinâmica rítmico-sonora. Digo também 'rítmica' porque o som repetido age na memória com valor de repetição e de acento. Mas estas forças socializadoras da rima só se valorizam perfeitamente quando ela está sistematizada e ocorrente em lugares esperados. A rima em poesia erudita, arbitrariamente dispersa entre versos brancos, perde a sua identidade musical e sua função, pra imediatamente excitar em nós um qualquer pensamento crítico. E este a percebe, na maioria das vezes, como ressonância inatenta do artista, como eco desagradável. E quando sistematizada no final do poema, como faz agora a poetisa, soa com tal ou qual bruteza, fortificando demasiado o acento do fim (que é natural), criando uma atmosfera indelicada de excessiva 'selfishness'. As ordens da arte se distanciam das militares, pela sutileza e escondido em que são ditadas (ANDRADE, 1972, p. 229).
\end{abstract}

Afora o vocabulário espontâneo, estranha no crítico o apuro técnico do comentário a quem esperasse qualquer elucubração de apelo nacionalista ou popular. Como se não fosse possível depurar um postulado teórico da forma, o crítico ensaia uma interpretação exemplar da poetisa justamente porque se afasta de qualquer simpatia pessoal ou ideológica e o efeito socializador é destacado justo da rima, elemento tão técnico que só dá acesso ao sentido do poema quando está à beira de seu esvaziamento referencial. Mas não é isso que se depreende do raciocínio exposto, segundo o qual da rima é que decorre a compreensão mais íntima e nítida da poesia em curso, uma vez que a rima utilizada por Adalgisa Nery em meio a versos brancos, consoante a compreensão acionada, adquire por sua força apelativa valor expressional incomum, porquanto radica um princípio de racionalidade desprovido da tonalidade melódica que a repetição instaura, para se transferir a outro nível da sensibilidade para o qual a 
expectativa de harmonia ou de dissonância não tem mais o valor de universalidade, que se desdobra em outro plano, onde a coletividade passaria a ser vista por outro ângulo.

O descolamento do elemento rítmico-sonoro para racional, ao mesmo tempo em que transfere o conhecimento musical para a ideia explicitada, cinde o valor expressivo da exposição no verso. Com isso, possibilita outra compreensão da subjetividade exposta no corpo do poema, tão cindida quanto o universo que quer representar e não encontra termo adequado na sua expressão. A formalização do impasse vem a ser o termo justo da novidade que a poetisa nos impõe, porque não se reduz a simples eco da liturgia católica, ou mesmo modalização da expressão verbal que ampara a mística religiosa, a exemplo do que foi anotado sobre a poesia praticada por Murilo Mendes ou por Jorge de Lima. Ao mesmo tempo em que Adalgisa Nery se nos oferece materialmente inscrita no verso, porque deslocada de sua própria expectativa, impede o curso livre da razão instrumental e se despede de todo mandamento cristão, para subscrever um imperativo vivo na linguagem que se oferece como correlato de sua experiência concreta, sem qualquer respaldo na liturgia em que chafurda. Como é difícil aceitar o raciocínio sem algum ressaibo insidioso, está explicado em parte o motivo pelo qual ela não se inscreveu na linearidade historiográfica que requer elementos simbólicos que valham para a toda a sociedade cristã que se quer brasileira, onde ela haverá de permanecer ausente.

\section{Referências}

ANDRADE, Mário de. Aspectos da literatura brasileira. Rio de Janeiro: Americ-Edit, 1943.

A mulher ausente. In: . O empalhador de passarinho. $3^{\mathrm{a}}$ ed. São Paulo: Martins; Brasília: INL, 1972. p. 227-230.

GUIMARÃES, Julio Castañon. Murilo Mendes: a invenção do contemporâneo. São Paulo: Brasiliense, 1986.

LIMA, Jorge. Poesia completa. Rio de Janeiro: Nova Aguilar, 1997.

MENDES, Murilo. Poesia completa e prosa. $2^{\text {a }}$ ed. Rio de Janeiro: Nova Aguilar, 1995.

NERY, Adalgisa. A mulher ausente. Rio de Janeiro: José Olympio Editora, 1940.

NERY, Ismael. A virgem inútil. In: BANDEIRA, Manuel (org.). Antologia de poetas brasileiros bissextos contemporâneos. Rio de Janeiro: Zélio Valverde, 1946.

Recebido em: 01/09/2019

Aceito para publicação em: 07/11/2019 